Studia i materiały z dziedzictwa kulturowego Torunia i regionu, t. 1: STARE I NOWE DZIEDZICTWO TORUNIA,

Toruń 2013

http://dx.doi.org/10.12775/SiMzDzKTiR_T1.2013.005

Krystyna Sulkowska-Tuszyńska

(IARCH UMK, TORUŃ)

\title{
Primum non nocere! O archeologicznych badaniach wokół toruńskiego kościoła św. Jakuba ${ }^{1}$
}

\section{O HISTORII, METODZIE BADAŃ I OPRACOWAŃ KOŚCIOŁA}

Rok 2013 będzie piątym sezonem archeologicznym, realizowanym przy kościele św. Jakuba w Toruniu. Dotąd w ciągu czterech kampanii wykopaliskowych ekspedycja Instytutu Archeologii UMK w najbliższym sąsiedztwie kościoła założyła jedenaście wykopów i trzy sondaże w celu rozpoznania początków Nowego Miasta i jego świątyni oraz historii klasztoru cysterek-benedyktynek. Osobnym wielkim zadaniem jest zbadanie nowomiejskiego cmentarza (il. 1).

Inauguracyjny sezon badań jakubowa ekspedycja zakończyła sukcesem w sierpniu 2008 roku $^{2}$, kolejne miesięczne kampanie przeprowadzono w latach 2010, 2011, 2012 (il. 3)3. Poszukiwania skupiono wokół prezbiterium świątyni oraz po jej południowej stronie, przy dawnym poklasztornym budynku, w którym od jesieni 2008 do końca 2009 roku, podczas generalnego remontu archeolodzy nadzorowali prace budowlane ${ }^{4}$. W 2013 roku rozpoczniemy eksplorację wokół masywu zachodniego.

Celem niniejszego artykułu jest zdanie ogólnej relacji z całości archeologicznych poczynań podjętych przy kościele św. Jakuba i pokazanie, jak bogate są wyniki i jak liczne - opra-

1 Tytuł nawiązuje do dyskusji, która odbyła się podczas obrad konferencji. Autorka zmierza do uzasadnienia konieczności prowadzenia badań archeologicznych w obrębie zabytkowych obszarów i pokazuje potrzebę prowadzenia uważnej eksploracji, wykonywania rzetelnej dokumentacji i analizy wydobytego materiału oraz bardzo ostrożnego interpretowania odkryć.

2 Wyniki pierwszych badań w 2008 roku patrz: Krystyna SULKOWSKA-TUSZYŃSKA, Apud terram, ante ecclesiam Niezapisane karty kościoła i parafi św. Jakuba w Toruniu, „Pomorania Antiqua”, t. 23, Gdańsk 2010, s. 249-273. Tam też literatura, nota o architekturze kościoła, problematyka badawcza i dyskutowane tezy.

3 Patrz plan wykopów, il. 3.

4 Wyniki badań opublikowano zaraz po zakończeniu długiego nadzoru: Krystyna SULKOWSKA-TUSZYŃSKA, Anna CICHA, Dawny klasztor przy kościele św. Jakuba w Toruniu i jego otoczenie w świetle badań archeologicznych $z$ lat 2008-2009, „Rocznik Toruński”, t. 37, 2010, s. 251-273. Patrz też dalsza literatura w artkule Anny CICHEJ $\mathrm{w}$ niniejszym tomie. 
cowania. Istotne jest też podejście do problemu, metodyka badań oraz realizacja tego złożonego zadania. Skalę trudności powiększają liczne ograniczenia.

Jak dotąd badania trwały łącznie zaledwie cztery miesiące, co jest jedynie namiastką dla rozpoznania tak bogatego w historię obiektu. Wykopaliska prowadzone były tylko na zewnątrz bryły i głównie wokół prezbiterium - ograniczenie obszaru wynikało z konieczności podporządkowywania się pracom remontowym i konserwatorskim na dachu i na wieży; po trzecie, eksploracja była prowadzona w ramach studenckich ćwiczeń terenowych: prace posuwały się stosunkowo wolno z uwagi na wymogi procesu dydaktycznego, ale zarówno obserwacje, jak dokumentacja oraz przebieg badań stały na bardzo wysokim poziomie. Badania te nie są związane $\mathrm{z}$ żadną inwestycją, dlatego limitowane są niewielkimi funduszami - w 2009 roku, z powodu braku jakichkolwiek funduszy, nie prowadzono eksploracji w terenie. Niektóre badania laboratoryjne zakończono, inne są w toku. Na opracowanie biologicznej i kulturowej populacji szkieletowej Nowego Miasta Torunia w 2009 roku Rektor UMK przyznał tzw. grant pomostowy ${ }^{5}$.

Do realizacji projektu i opracowania wszystkich dotychczasowych odkryć wykorzystywany jest ogromny potencjał naukowy, zarówno ekspedycji wykopaliskowej, Instytutu Archeologii UMK, jak i specjalistów z innych instytucji ${ }^{6}$. W ramach prac ekspedycji został też wykonany nowy plan kościoła św. Jakuba, w skali 1:100. Jest to rzut przyziemia od zewnątrz, wyprowadzony spod łuku tęczowego ${ }^{7}$.

5 Grant ten dotyczył wyników pierwszych wykopalisk (materiał wydobyty z wykopów: W-1,2,3/08) zatem, w stosunku do dalszych poczynań, obejmował mniejszość odkryć. Szczątki ludzkie odkryte na terenie przykościelnego cmentarza (83 groby i luźne kości) zostały poddane badaniom genetycznym (mt DNA) i kompleksowym analizom antropologicznym. Celem projektu było ukazanie cmentarza i obrządku pogrzebowego w Nowym Mieście Toruniu, od przełomu XIII i XIV wieku po stulecie XIX, ze wskazaniem na jego dzieje katolickie i protestanckie. Całość realizowana jest w Instytucie Archeologii UMK pod kierunkiem dr hab. K. Sulkowskiej-Tuszyńskiej, prof. UMK; część dotycząca analiz genetyczno-antropologicznych wykonana została w Katedrze Medycyny Sądowej CM UMK w Bygoszczy pod kierunkiem prof. dr. hab. T. Grzybowskiego.

6 Poza wspomnianymi wyżej badaniami genetycznymi kontynuowane są analizy szczątków ludzkich (Jarosław Bednarek). Badania palinologiczne szczątków roślinnych wykonuje Agnieszka Noryśkiewicz, ratowaniem zniszczonych obiektów zajęli się konserwatorzy zabytków archeologicznych - Marek Kołyszko (konserwacja kamiennej misy, rekonstrukcja kształtów i anastyloza ceramiki) oraz Małgorzata Grupa i Anna Drążkowska (konserwacja fragmentów tkanin, zabezpieczenie i mikroskopowa analiza metalowych elementów wianków). Analizy antrakologiczne drewna i badania środowiska przyrodniczego wykonuje Dorota Bienias, a datowanie radiowęglowe drewna - Marek Krąpiec. Numizmatami i ich konserwacją zajmują się Adam Musiałowski i Violetta Stawska. Cegłę metodą termoluminescencji (TL) datują Alicja Chruścińska i Krzysztof Piętka. Problematykę parafii i klasztoru przy kościele św. Jakuba w Toruniu zgłębia Anna Cicha, przygotowując dysertację doktorską. Stratyfikację stanowiska, początki osadnictwa, pierwotny plan i wyposażenie kościoła oraz kulturę torunian na postawie badań archeologiczno-architektonicznych rozpoznaje Krystyna Sulkowska-Tuszyńska. Badania petrograficzne wykonali Halina Pomianowska i Wojciech Bartz, a analizy chemiczne powłok na misie chrzcielnej Dorota Sobkowiak z Elżbietą Orłowską. Obserwacje architektoniczne prowadzi Bożena Zimnowodna-Krajewska. Szczątki zwierzęce oceniają Daniel Makowiecki i Mirosława Zabilska, a makroszczątki Joanna Abramow. Dokumentacją fotograficzną wraz ze wstępną obróbką zdjęć zajmuje się Joanna Struwe, a nad całością poczynań kierowników wykopów czuwa Anna Cicha wraz z innymi doktorantami. Kierownikiem ekspedycji i opiekunem uczących się studentów jest Krystyna Sulkowska-Tuszyńska

7 Wykonany w 2010 roku na podstawie sześciuset pomiarów Mariusza Tuszyńskiego, narysowany w 2013 roku przez Wojciecha Miłka dopiero w 2013 roku z powodu nagłej śmierci Mariusza Tuszyńskiego (2010). Siatkę arową na eksplorowanym obszarze w 2008 roku wykonał M. Tuszyński. 


\section{O POTRZEBIE ARCHEOLOGICZNYCH POSZUKIWAŃ}

Obok badaczy zafascynowanych wręcz omawianą tu unikatową gotycką kreacjąa ${ }^{8}$ jej historią, bryłą, wyposażeniem - są i tacy, którzy sceptycznie patrzą na archeologów, pytając o celowość prowadzonych przez nich badań. Bogata historia obiektu, unikatowa wartość nadal funkcjonującej świątyni oraz zły stan zachowania jej wnętrza, pilnie wymagają solidnych badań i kapitalnego remontu - zakończono już remont dachu, trwają prace konserwatorskie na wieży w masywie zachodnim, jest zatem wielki czas na poszukiwania archeologiczne $^{9}$. Dla archeologa, po zapoznaniu się z zapisaną historią obiektu, jeszcze przed wykopaliskami - a tym bardziej po pierwszym sezonie wykopaliskowym - było oczywiste, że jakubowe tajemnice znajdują się także poniżej powierzchni gruntu, i co najważniejsze - tam właśnie „zapisana” jest historia, której okresów, dat, ani osób nie zanotował żaden kronikarz. Niektóre odkrycia dostarczają zagubionych monet (il. 4), inne ilustrują codzienne czynności lub pokazują elementy ubioru i wyposażenia wnętrz (il. 5, 6, 8 b, d), inne mają wręcz podstawowe znacznie dla wyjaśnienia dyskusyjnych kwestii, które bez archeologów nigdy nie mogłyby zostać rozwiązane. Szczególnie istotna w takich badaniach jest precyzja - dlatego, by wychwycić z eksplorowanej materii możliwie wszystkie ślady działalności człowieka, najstarsze jednostki kulturowe są przesiewane przez sita. Trzeba tu wyraźnie podkreślić, że tzw. nieinwazyjna archeologia w swoich efektach daje bardzo ograniczone i niejasne obrazy; jest także kosztowna. Warunkiem sine qua non uczciwych archeologicznych poszukiwań jest przestrzeganie kilku zasad, które musi stosować każdy rzetelny badacz: ostrożna eksploracja, wnikliwa obserwacja, wierna dokumentacja oraz interpretacja poparta udokumentowanymi artefaktami. Obecnie transdyscyplinarny charakter badań nie podlega dyskusji - powinien być standardem, a publikacja wyników powinna wieńczyć dzieło.

Należy jeszcze dodać, że źródła pisane, dotyczące średniowiecznych dziejów kościoła św. Jakuba są nieliczne, dane zaś są lakoniczne, o niejednoznacznej wymowie; niektóre wiadomości czerpane są z niepotwierdzonych, dużo młodszych źródeł.

\section{ARTEFAKTY ODKRYTE PODCZAS BADAŃ ARCHEOLOGICZNO-ARCHITEKTONICZNYCH}

Spośród obiektów, pochodzących z najstarszej fazy funkcjonowania kościoła, najważniejsza i najpiękniejsza jest kamienna misa chrzcielna odkryta w pierwszym sezonie badań - w pierwszych godzinach eksploracji - przed bocznym portalem prezbiterium (wykop W2/08), w warstwie remontowo-budowlanej z XIX wieku. Obiekt o średnicy $55 \mathrm{~cm}$, jest półkulisty we wnętrzu, oktogonalny na zewnątrz (il. 7). Na zachowanych częściowo ściankach

8 Patrz różne artykuły o historii, wyposażeniu i metodach badań tego kościoła: Dzieje i skarby kościoła Świętojakubskiego w Toruniu, red. K. KLUCZWAJD, Toruń 2010. Tam też starsza literatura.

9 Wątpiącym w zasadność wykonania takich badań przybliżamy literaturę naukową i popularną, wykazy prac dyplomowych napisanych w oparciu o nowe dane o kościele, z których wiele zostało nagrodzonych, a jedna już opublikowana: Aleksandra GRZYB, Przedmioty znalezione na cmentarzu przy kościele św. Jakuba w Toruniu: wyniki badań archeologicznych, „Rocznik Toruński”, t. 38, 2011, s. 157-168. Odsyłamy również do bloga: www.archeologiajakubowa.wordpress.pl. 
widać lwy kroczące dookoła, ukazane na powierzchni zewnętrznej, pod arkadami.

Badania wykazały, że misa została wykonana z gotlandzkiego wapienia. Po pewnym okresie używania, jej wewnętrzną powierzchnię odświeżono kremową, kazeinowo-wapienną powłoką. Jest bardzo prawdopodobne, że obiekt ten należy do najstarszych kamiennych mis sprowadzanych przez Krzyżaków z Gotlandii do wielu kościołów ich państwa w XIII i XIV wieku. Jest też możliwe, chociaż jeszcze nie potwierdzone, że sprowadzono jedynie kamień, a misę naśladującą w skromniejszej wersji stosowany na Gotlandii program ikonograficzny, wykuł wyjątkowo zdolny miejscowy lapicida ${ }^{10}$. Używanie takiego obiektu przy kościele św. Jakuba świadczy o kontaktach ze strefą bałtycko-hanzeatycką.

Nieliczna bardzo jest grupa naczyń ceramicznych, które ze względu na kształt i technologię wykonania reprezentują typowe dla okresu z około XIII wieku tzw. naczynia tradycyjne, o chropowatej brunatnej powierzchni, skromnie zdobione rytym ornamentem. Niestety, sama ceramika ma mało dystynktywne cechy. Fakt ten nie jest dla archeologa zdumiewający - są to nieliczne fragmenty pochodzące z najstarszej jednostki kulturowej (znad calca), z terenu, gdzie od około XIII-XIV wieku aż do lat 30. XIX wieku funkcjonował cmentarz; jakiekolwiek codzienne utensylia dostawały się na ten obszar przypadkiem i wyjątkowo. Dużej ilości ceramiki spodziewamy się blisko budynków klasztornych ${ }^{11}$.

Do najstarszych i nielicznych należą również krzyżackie denary brakteatowe, ołowiane plomby (il. 8 d) i dwuteowniki od szkieł witrażowych, żelazne sprzączki od pasów i butów (il. 8 b) oraz wędzidła końskie, kamienne formy odlewnicze, fragmenty kościanych grzebieni i zawieszek oraz brązowe okucie końcówki pasa. Znaleziono także okładziny trzonków noży (?) z nitami (il. 5), kościane krążki z otworkiem, pojedyncze klucze i kłódki, końskie podkowy (niekiedy z podkowiakami, il. $8 \mathrm{c}$ ), ceramiczne kulki o średnicy około $1 \mathrm{~cm}$, fragmenty popularnych w XIV-XV wieku naczyń stalowoszarych, nieliczne ułamki naczyń kamionkowych sprowadzanych w XV-XVII wieku głównie z Nadrenii i Saksonii oraz fragmenty kafli. Może jeszcze w średniowiecznym okresie używane były ołowiane żetony i kamienna kula działowa, znaleziona w posadzce tzw. łącznika ${ }^{12}$ oraz fragmenty kafli (il. 8 a, 9).

Najciekawszym zabytkiem - wstępnie datowanym na około XVII stulecie - jest kameryzowana brosza w kształcie rozety wykonana ze srebrnej blachy, ze szlifowanymi szklanymi (?) oczkami; bardzo podobna do biżuterii ozdabiającej portretowanych patrycjuszy Torunia, których podobizny zachowały się w toruńskim ratuszu. Jest też wiele monet: denar węgierski (1601 r.), szelągi litewskie, elbląskie i toruńskie, w przewadze z drugiej połowy XVII wieku, fragmenty kafli płytowych oraz cybuchy i główki jednorodnych fajek holenderskich (il. $10 \mathrm{a}$ )

10 Krystyna SULKOWSKA-TUSZYŃSKA, Kamienna misa chrzcielna z kościoła św. Jakuba w Toruniu, „Slavia Antiqua”, t. 53, 2012, s. 187-206.

11 Patrz wyniki nadzoru archeologicznego podczas remontu budynku poklasztornego i systematycznych badań archeologiczno-architektonicznych pomiędzy kościołem a klasztorem: SULKOWSKA-TUSZYŃSKA, CICHA 2010, s. 251-273; Anna CICHA, Niełatwe odkrywanie klasztoru toruńskich cysterek-benedyktynek, czyli o badaniach archeologiczno-architektonicznych z lat 2008-2010, [w:] Forum Scientiae Cisterciense. Przyszłość badań nad historia i kultura cysterska $w$ Polsce, red. E. ŁUŻYNIECKA, A. GALAR, Wrocław 2011, s. 181-196; TAŻ, Klasztor cysterek-benedyktynek przy kościele św. Jakuba $w$ Toruniu $w$ świetle źródeł ikonograficznych $i$ archeologicznych, [w:] Dzieje i skarby kościoła Świętojakubskiego w Toruniu, red. K. KLUCZWAJD, Toruń 2010, s. 141-159.

12 Patrz A. CICHA w niniejszym tomie. 
oraz grawerowana obrączka na palec. Zapewne z XVIII wieku pochodzą liczne elementy wyposażenia coraz powszechniej stosowanych trumien: gwoździe, ćwieki, ozdobne okucia w kształcie gwiazdek i rozetek oraz wianki grobowe, o czym niżej. Poza kaflami i licznymi dachówkami, odkryto też fragmenty różnych naczyń, w tym kamionkę łużycką, liczman Ludwika XVI oraz drewniane i kościane guziki.

Z XIX i początku XX wieku pochodzą fajki złożone, pojedyncze monety - jak 10 pfennigów z 1876 roku, szklana butelka z niemieckim napisem, a przede wszystkim ciekawy zespół krucyfiksów zdeponowany wokół zakrystii (kilka metalowych, jeden porcelanowy ze złoconym perizonium, il. $10 \mathrm{~b}$ ).

Zupełnie inny rodzaj tzw. zabytków ruchomych tworzą drobne elementy, znalezione w grobach, umownie nazwane tu „wyposażeniem grobowym”. Są wśród nich liczne wiązki drucików (brązowe, srebrne) - pogiętych, plecionych i pofalowanych - oraz występujące czasami w ich kontekście łańcuszki z drutu brązowego i liczne szpilki krawieckie (długość ca $3 \mathrm{~cm}$; wyjątkowo do $7 \mathrm{~cm}$ ). Tu także zdarzały się fragmenty wstążek i tkanin, niekiedy ze szpilkami i wiązkami włosów. Niektóre druciki lśniły - jak wykazały badania mikroskopowe, były to nici srebrne lub złote, którymi owijano druciki ${ }^{13}$. W nowożytnych jamach grobowych odkryto też srebrne haftki do ubrań i kościane guziki. Poza nielicznymi paciorkami, które mogły pochodzić od różańców, w nowożytnych warstwach jakubowego cmentarza nie stwierdzono dewocjonaliów. Wnioskując z dotychczasowych badań różnych chrześcijańskich nekropolii wolno mi sugerować, że dewocjonalia powszechne były w XVII i XVIII wieku, ale zwyczaj ten stosowano głównie w miejscach, które w całej swojej historii były wyłącznie katolickie, natomiast zupełnie inaczej problem ten rysuje się w przypadku cmentarzy, z których korzystali katolicy i protestanci. Wydaje się, że w znacznej mierze zwyczaj obdarowywania zmarłych wiankami i rezygnowania z dewocjonaliów można łączyć z wpływami reformacji i przekonaniami protestantów. Zjawisko to pilnie wymaga dalszych badań.

Wstępnie można założyć, że na nowotoruńskiej nekropolii „szczególnych” zmarłych obdarzano wiankami ${ }^{14}$. Po czterech sezonach badań ${ }^{15}$ można już stwierdzić, że niektórym zmarłym do grobu wkładano wianki o różnej budowie. Najprostsze były wianki bez konstrukcji nośnej (typ 1), składające się z 1-3 okółków plecionej z drucików podstawy na kształt sznurka, który miał szerokość około 3-5 mm. By wianek podnieść w górę, tak aby był widoczny nad włosami, wokół podstawy faliście wplatano w niego kolejne sznurki. Nieco

13 Mikroskopowe badania drucików i nici wykonuje i interpretuje Małgorzata Grupa.

14 Wstępnego opracowania wianków z pierwszego sezonu badawczego w 2008 roku, już w 2011 roku dokonała A. Cicha: Anna CICHA, Wieniec (...) został dla mnie upleciony: pochówki w wiankach z cmentarza przy kościele św. Jakuba w Toruniu, [w:] Obraz struktury społecznej w świetle źródeł archeologicznych w pradziejach i średniowie$c z u$, red. M. RYBICKA, Rzeszów 2011, s. 187-197

15 Już po pierwszym sezonie badań w oparciu o wyniki badań cmentarza powstało kilka prac licencjackich, w tym dwie o pochówkach: Ewelina CHOŁODOWSKA, Wianki z grobów przy kościele św. Jakuba w Toruniu. Charakterystyka i symbolika (badania archeologiczne w 2008 roku), Toruń 2009; Marta MANDRYTO, Nowożytny pochówek z wiankami na cmentarzu przy kościele św. Jakuba w Toruniu (badania archeologiczne w 2008 roku): Prace lic. wykonane w IA UMK na seminarium K. Sulkowskiej-Tuszyńskiej, maszynopis w IA UMK, Toruń, Szosa Bydgoska 44/48. 
bardziej złożoną budową charakteryzują się wianki oparte na wykonanej z miękkiego drewna listewce o szerokości 7-10 mm (typ 2), dokładnie owiniętej drucikiem z jedwabną nitką lub metalową owijką - taką konstrukcję faliście przeplatały plecione warkoczyki, identyczne jak w wyżej opisanym wianku (typ 1). Kolejny typ (3), zbliżony do typu drugiego, to wianek na drewnianej listewce ozdobionej setkami cekinów: kolistych cienkich blaszek o średnicy 3-8 mm, nanizanych na druciki.

Wiankami ozdobiono ciała około 25 \% zmarłych, w okresie od około XVI do XVIII wieku. Zwykle kładziono je na głowę przyczepiając do włosów cienkimi drucikami, a do odzieży krawieckimi szpilkami. Wkładano je głównie (choć nie wyłącznie) do grobów dzieci, młodzieńców i osób stanu wolnego, również zakonnicom. Cały wianek bywał wzbogacony drobnymi kwiatami o żywych barwach, ziołami lub zielonymi gałązkami chwastów powszechnie rosnących przy drogach ${ }^{16}$ oraz jedwabnymi wstążeczkami. Wciąż brakuje danych do udowodnienia bardzo prawdopodobnej tezy, że zwyczaj obdarowywania zmarłych wiankami rozpowszechnił się głównie na tych terenach i praktykowany był na takich cmentarzach, gdzie wpływy reformacji były wczesne i silnie zakorzenione.

\section{O FUNDAMENTACH ${ }^{17}$ - GŁOSY ARCHEOLOGA}

Odkrycie, rozpoznanie i interpretacja fundamentów kościoła oraz różnych reliktów architektury zachowanej in situ wokół bryły, składają się na ważką problematykę rozpoczęcia budowy kościoła św. Jakuba oraz ewentualne powiązanie tego faktu z lokacją Nowego Miasta Torunia i historią zabudowy kościelnego kwartału. W literaturze przedmiotu bezsporną kwestią jest położenie w 1309 roku kamienia węgielnego pod budowę analizowanego kościoła, co wynika z łacińskiej inskrypcji zachowanej na murach prezbiterium ${ }^{18}$. Niektórzy badacze uważają, że wcześniej istniał w tym miejscu kościółek drewniany, rozebrany na krótko przed budową w 1309 roku. Absolutnym wyjątkiem w dyskusji, w której nie można było jeszcze uwzględnić wyników badań archeologicznych (!), jest przekonanie Otto Freymutha, poparte wyjątkowo drobiazgowymi rozważaniami - sądził on, że pierwotny kościół został wzniesiony najpóźniej w 1264 roku, czyli w okresie lokacji Nowego Miasta ${ }^{19}$, lub na-

16 Badania palinologiczne dr Agnieszki Noryśkiewicz trwają. Po wykonaniu kilku prób palinolog stwierdziła, że do wianków wkładane były drobne kwiaty o żywych barwach i pospolite zioła. Przygotowywana jest publikacja o wiankach grobowych i ich odmianach oraz rekonstrukcja z wykorzystaniem badań archeologa, antropologa i palinologa.

17 W ramach niniejszego artykułu formułuję jedynie kilka ogólnych informacji. Problem jest złożony, badania są w toku, do wyjaśnienia niektórych kwestii będzie konieczna eksploracja we wnętrzu kościoła.

18 Patrz starsza i nowsza literatura przedmiotu w: Liliana KRANTZ-DOMASŁOWSKA, Jerzy DOMASŁOWSKI, Kościół świętego Jakuba w Toruniu, („Zabytki Polski północnej” 2, Towarzystwo Naukowe w Toruniu), Toruń 2001; Dzieje i skarby kościoła Świętojakubskiego w Toruniu, Dzieje i skarby kościoła Świętojakubskiego w Toruniu. Materiały z IV Sesji Naukowej Toruńskiego Oddziału SHS, z cyklu Dzieje i skarby kościołów toruńskich, zrealizowanej przy współpracy Biblioteki Uniwersyteckiej UMK w Toruniu, 26-28 października 2009 roku, red. K. KLUCZWAJD, Toruń 2010.

19 Otto FREYMUTH, Untersuchungen zur mittelalterlichen Baugeschichte der Neustädter Pfarrkirche St. Jakobi $z u$ Thorn, [w:] Thorn - Königin der Weichsel 1231-1981, „Beiträge zur Geschichte Westpreußens. Zeitschrift der Copernicus-Vereinigung zur Pflege der Heimatkunde und Geschichte Westpreussens e.V.", Bd. 7, Hg. B. JÄHNIG, P. LETKEMANN, Göttingen 1981, s. 13-98. 
wet wcześniej. Z kolei - jak słusznie zauważył Tomasz Jasiński - z planu miasta wynika, że u progu lokacji, podczas wytyczania ulic, uwzględniono miejsce na kościół parafialny ${ }^{20}$.

$\mathrm{Na}$ obecnym etapie badań archeologicznych, które mają ograniczony charakter i zasięg można stwierdzić, że relacja stratyfikacyjna: fundament - bryła prezbiterium jest zakłócona i nosi w sobie ślady dwóch etapów prac budowlanych. W wykopach założonych wokół pierwszej (W-6/11) i drugiej od wschodu skośnej skarpie prezbiterium (W-3/08) i po jego południowej stronie (W-11/12) odsłonięty kamienny fundament (wysoki do $3 \mathrm{~m}$ ) jest jednorodny, ale jego przebieg w stosunku do bryły ponad poziomem użytkowym jest różny pod pierwszymi od wschodu skośnymi skarpami jest ustawiony zgodnie z ich przebiegiem, czyli pod kątem ostrym do osi prezbiterium, a pod drugimi, pod kątem prostym. Widać też, że skarpy ustawione inaczej niż ich fundament, są znacznie krótsze i węższe od niego oraz, że nie mają odsadzek. Największą jednak „fundamentową” niespodzianką wszystkich sezonów wykopaliskowych było odkrycie w 2012 roku części potężnego kamiennego fundamen$\mathrm{tu}$, wysuniętego przed boczny portal prezbiterium o około $3,2 \mathrm{~m}^{21}(\mathrm{~W}-10 / 12$, il. 11).

$\mathrm{Na}$ obecnym etapie badań istnieją co najmniej dwie możliwości wyjaśnienia tego zjawiska. Odkryty fundament mógł wspierać inną, starszą świątynię wzniesioną w XIII wieku, gdy powstawało Nowe Miasto Toruń (około 1264 roku). Możliwe jest także, iż architekt budując kościół św. Jakuba od około 1309 roku zmienił koncepcję co do przebiegu drugich od wschodu skarp i na prostopadłym do osi fundamencie polecił oprzeć przekątniowe przypory. By możliwe było wyjaśnienie postawionych hipotez, koniecznie należy założyć wykopy jeszcze w kilku miejscach na zewnątrz i wewnątrz kościoła.

\section{O CMENTARZU}

Po czterech kampaniach archeologicznych nie ulega wątpliwości, że parafialny cmentarz otaczał prezbiterium dookoła, dochodząc bezpośrednio do bryły. Dotąd, w obrębie jedenastu analizowanych wykopów o średniej powierzchni $12 \mathrm{~m}^{2}$ (łącznie zbadano około $130 \mathrm{~m}^{2}$ powierzchni gruntu), odsłonięto łącznie 249 grobów jednostkowych i dwa ossuaria (il. 12). W sezonie 2008, w wykopach W-1,2,3/08 odkryto 83 groby, w 2010 (W-4,5/10) - po południowej stronie - 32 jamy grobowe. W obrębie wykopów W-6,7,8/11 wyeksplorowano w 2011 roku razem 54 groby, a w roku 2012 (W- 9,10,11/12) aż 80 grobów. W najmłodszych poziomach wykopu W-11/12, pomiędzy skarpami znaleziono duże ossuarium.

Wstępne rezultaty pierwszych sezonów badań już opublikowano ${ }^{22}$ lub opracowano w ramach prac dyplomowych. Dotychczasowe wyniki wskazują na istnienie w różnych kwate-

20 Tomasz JASIŃSKI, Toruń XIII-XIV wieku -- lokacja miast toruńskich i początki ich rozwoju (1231- około 1350), [w:] Historia Torunia, red. M. BISKUP, t. 1, W czasach średniowiecza (do roku 1454), Toruń 1999, s. 100-166.

$21 \mathrm{~W}$ tym miejscu koniecznie trzeba założyć wykop tuż przy progu średniowiecznego portalu, obudowanego w XIX w. Plan fundamentów kościoła św. Jakuba w pierwotnej postaci będzie przedmiotem oddzielnej analizy, wzbogaconej wynikami datowania termoluminescencyjnego.

22 Patrz: SUlKOWSKA-TUSZYŃSKA 2010, s. 259-264 i n.; Krystyna SUlKOWSKA-TUSZYŃSKA, Agnieszka GÓRZYŃSKA, Dawne cmentarze nowomiejskie w świetle badań archeologicznych, [w:] Cmentarz Św. Jakuba i inne chrześcijańskie cmentarze nowomiejskie, red. K. MIKULSKI, Toruń 2010 (dalej cyt. CMENTARZ ŚW. JAKUBA 2010), s. 39-46; GRZYB 2011. Trwają badania Jarosława Bednarka nad populacją szkieletową cmentarza przykościelnego. 
rach cmentarza od siedmiu do jedenastu poziomów grobów, w których dominują beztrumienne pochówki, w tym groby dzieci i młodych kobiet, zwykle bez wyposażenia i, co istotne, bez dewocjonaliów, które w XVIII i XVIII wieku na katolickich nekropolach bardzo często wkładano do grobów. Zjawiskiem, wymagającym oddzielnych studiów i dalszych obserwacji jest zwyczaj wkładania wianków na głowy i inne części ciała zmarłych - dzieci, młodych osób stanu wolnego czy zaślubionych Bogu zakonnic.

Przykościelna nekropolia św. Jakuba od XIII/XIV wieku do lat 50. XVI wieku służyła katolikom, później - przez sto dziesięć lat - protestantom, a od drugiej połowy XVII wieku znowu była katolicka, aż do lat 30. XIX wieku. Po tym czasie zaprzestano już grzebania zmarłych przy kościele; funkcje grzebalne przejęły cmentarze na Jakubskim Przedmieściu ${ }^{23}$.

Podsumowując, należy jedynie dodać, iż rzetelne badania archeologiczne w żadnej mierze nie zaszkodzą świątyni, a ich rezultaty pozwolą na dopisanie niejednej ważkiej glosy, rozjaśniającej dzieje nowotoruńskiej parafii i miasta Torunia; bez wątpienia wzbogacą też listę skarbów kościoła św. Jakuba.

\section{综漟 综}

\section{Primum non nocere! \\ On archaeological research in the graveyard around St. James church in Toruń}

The article sums up the first four seasons of archaeological-architectonic studies performed around gothic body of St. James church in Torun in 2008, 2010-2012. The authoress' purpose was also to emphasize the crucial role of archaeological studies in learning and reconstructing unknown pages of Torun town history.

Part I contains information concerning history and archaeological exploration methods and the latest publications on the studied church, based on archaeological excavations. The research was conducted by the Institute of Archaeology of NCU and lasted during four onemonth long excavation sessions with the participation of archaeological students and doctoral students of NCU - the excavations were also treated as field trainings for the partakers. In 2009 NCU President awarded a grant for preparing the study results (examining skeletal population and complex analyses of excavated objects and artifacts). Archaeological team and the specialists cooperating with it create interdisciplinary group (archaeologists, anthropologists, genetics, palynologists, numismatists, biologists, art restorers, physicists, chemists, architects, historians).

Part II focuses on the necessity of archaeological studies performed carefully, precisely evidenced and published, which is essential due to the fact that the majority of mediaeval docu-

23 Magdalena NIEDZIELSKA, Cmentarze na Jakubskim Przedmieściu - ewangelicki i katolicki, [w:]CMENTARZ ŚW. JAKUBA 2010, s. 15: „Na początku 1837 roku powiadomiono parafię św. Jakuba o ostatecznym zamiarze likwidacji starego cmentarza”. 
ments concerning St. James church and the parish have not preserved until present times.

Part III describes movable artifacts excavated around the church, in the area of its former graveyard. Apart from human remains, reported in predominance (249 single graves and two ossuaries were examined), the excavated objects included grave equipment (grave wreaths, jewelry, parts of garments), as well as fragments of coffin wood, signs of burial pits, traces of everyday life of the parish dwellers and Cistercian-Benedictine nuns (small fragments of ceramic vessels, tiles, roof tiles, pipes), trade activity (coins, tokens, seals) and religious practices (small crosses, crucifixes). Exceptional finds consist of mediaeval stone bowl, a cannon ball and a silver broach, decorated with jewels from 17 th $\mathrm{c}$.

Part IV refers to archaeologist's gloss concerning incompatibility of the lines and sizes of the church foundations in reference to the church body from 1309, what can suggest that the erecting process was performed in two stages or rather based on older foundations from the New Town location period (1264).

Part $V$ consists of the remarks on the graveyard surrounding the presbytery. The deceased parish members (?) were buried close to one another, usually along the temple walls, with their bony faces directed towards the East, without any coffins or buried in them only occasionally in modern times. Two secondary collective graves - ossuaries - were also excavated close to the church walls.

Summing up, it was emphasized that careful and detailed archaeological studies will make it possible to add many important remarks to the discussion on the parish history and treasures, monuments and relics. 


\section{SPIS ILUSTRACJI:}

1. Toruń, kościół św. Jakuba. Bryła kościoła z 1309 roku, widok od północnego wschodu na łuk przyporowy nad zakrystią, pinakle na przyporach i górną partię wieży w masywie zachodnim (stan $\mathrm{z}$ roku 2012, w trakcie renowacji), fot. J. Struwe.

2. Toruń, kościół św. Jakuba. Fundament korytarza (2. poł. XVII w.) łączącego boczny portal prezbiterium z klasztorem, pospiesznie postawiony na terenie ówczesnego cmentarza - widok z góry na ceglany fundament i zniszczone nim groby, fot. J. Struwe.

3. Toruń, kościół św. Jakuba. Plan wykopów 2008-2012 wokół wschodniej partii kościoła (W-1/08 do W-11/12); na podstawie planu A. Koniecznego, oprac. A. Cicha.

4. Toruń, badania archeologiczne wokół kościoła św. Jakuba - monety: brakteat krzyżacki i solid (1693); A - rys. N. Grzeszczuk, B - fot. J. Struwe.

5. Toruń, kościół św. Jakuba, badania archeologiczne w 2012 roku - dwuczęściowa oprawka trzonka noża z nitami; fot. J. Struwe.

6. Toruń, kościół św. Jakuba, badania archeologiczne w 2012 roku - ceramiczne szkliwione płytki posadzkowe zdobione motywem lilii; A - fot. J. Struwe; B - rys. E. Wielocha.

7. Toruń, kościół św. Jakuba. Kamienna misa (2 poł. XIII - 1. poł. XIV w) odnaleziona przed bocznym portalem - widok na dno i ścianki zewnętrzne z wypukłym reliefem - stan po konserwacji, fot. A. Cicha.

8. Toruń, kościół św. Jakuba, badania archeologiczne w 2010-2012 roku. Metalowe przedmioty znalezione wokół kościoła: A - ołowiany (?) żeton, B - sprzączka (rys. N. Grzeszczuk); C - żelazna podkowa z podkowiakami, D - ołowiana plomba (rys. E. Bełkowska-Kamińska).

9. Toruń, kościół św. Jakuba, badania archeologiczne w 2012 roku - kamienna kula działowa (obwód: $53 \mathrm{~cm}$, średnica $17 \mathrm{~cm}$ ), fot. J. Struwe.

10. Toruń, kościół św. Jakuba, badania archeologiczne w 2011-212 roku. A - główka porcelanowej fajki złożonej, XIX w. (rys. J. Ciesielska). B - porcelanowa figura Chrystusa znaleziona przy zakrystii (rys. B. Lechowicz).

11. Toruń, kościół św. Jakuba, badania archeologiczne w 2012 roku. Wykop W-10/12 przy bocznym portalu prezbiterium - widok na ceglany fundament wieżyczki schodowej (skośny, w głębi) i (na pierwszym planie) potężny kamienny fundament pod portalem i przyporą, fot. A. Cicha.

12. Toruń, kościół św. Jakuba, badania archeologiczne w 2011 roku (wykop W-6/11) - jeden z grobów odsłoniętych na przykościelnym cmentarzu [G-23/11], fot. J. Struwe. 


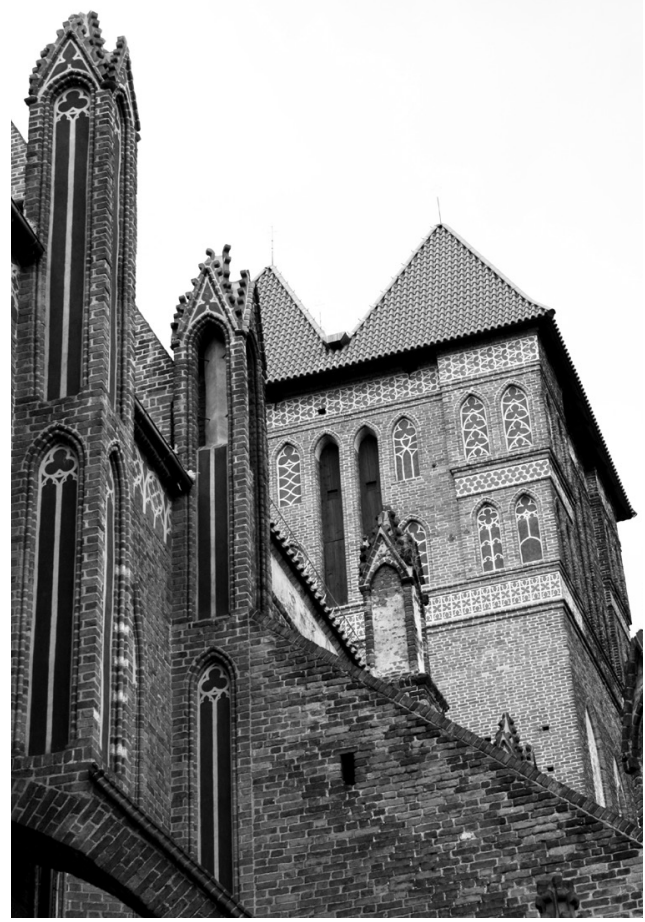

Il. 1 Toruń, kościół św. Jakuba. Bryła kościoła z 1309 roku, widok od północnego wschodu na łuk przyporowy nad zakrystią, pinakle na przyporach i górną partię wieży w masywie zachodnim (stan $\mathrm{z}$ roku 2012, w trakcie renowacji), fot. J. Struwe.

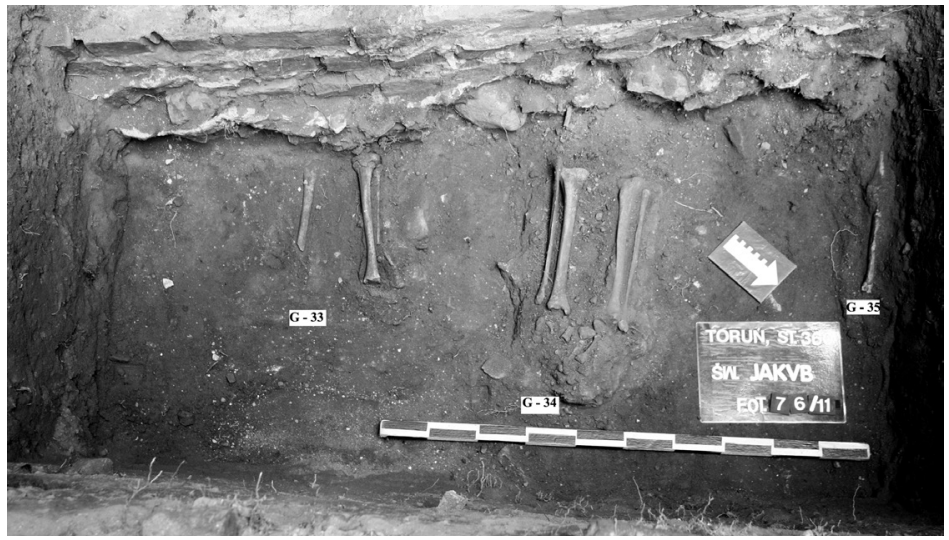

Il. 2 Toruń, kościół św. Jakuba. Fundament korytarza (2. poł. XVII w.) łączącego boczny portal prezbiterium $z$ klasztorem, pospiesznie postawiony na terenie ówczesnego cmentarza - widok z góry na ceglany fundament i zniszczone nim groby, fot. J. Struwe. 


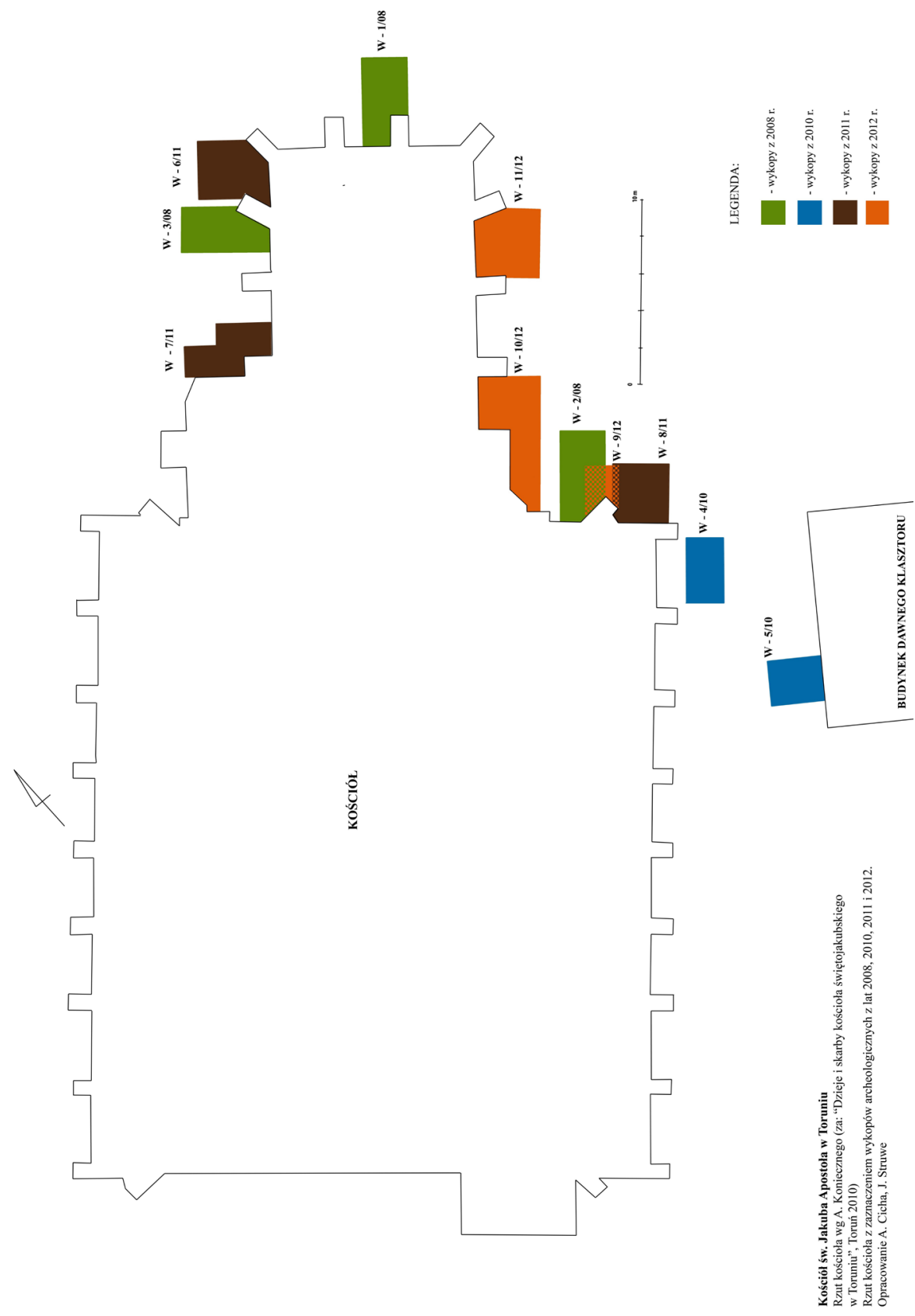

Il. 1 Badania wykopaliskowe przy kościele św. Jakuba Apostoła w Toruniu - plan wykopów z lat 2008-2012, opr. A. Cicha i J. Struwe na podstawie rzutu kościoła autorstwa Aleksandra Koniecznego z publikacji Dzieje i skarby kościoła Świętojakubskiego w Toruniu, Toruń 2010, il. 23 

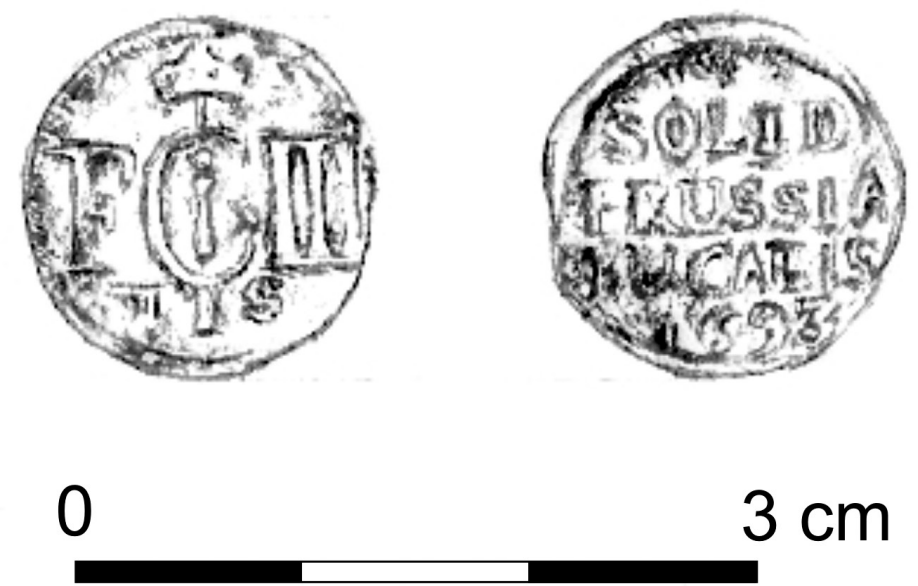

A

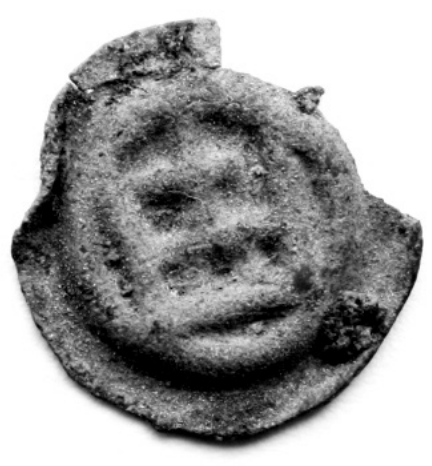

0

Il. 4 Toruń, badania archeologiczne wokół kościoła św. Jakuba - monety: brakteat krzyżacki i solid (1693); A - rys. N. Grzeszczuk, B - fot. J. Struwe. 


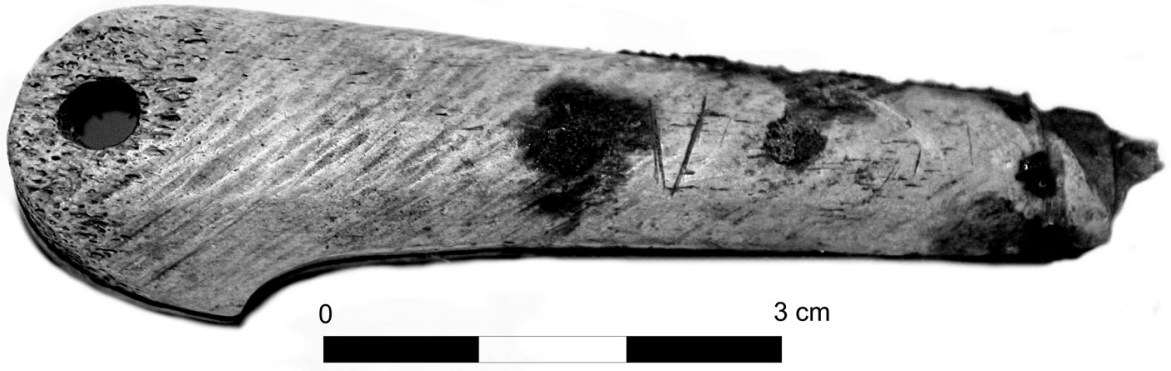

Il. 5 Toruń, kościół św. Jakuba, badania archeologiczne w 2012 roku - dwuczęściowa oprawka trzonka noża z nitami, fot. J. Struwe

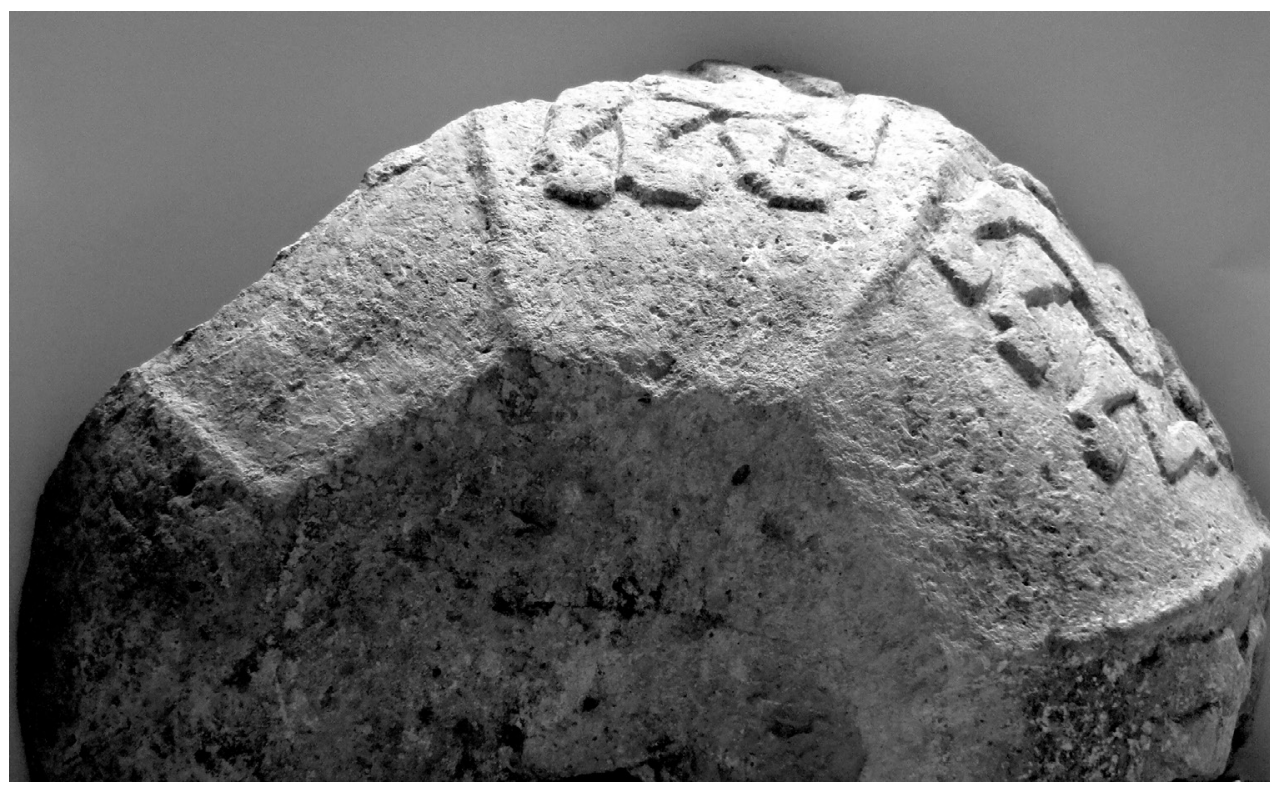

Il. 7 Toruń, kościół św. Jakuba. Kamienna misa (2 poł. XIII - 1. poł. XIV w) odnaleziona przed bocznym portalem - widok na dno i ścianki zewnętrzne z wypukłym reliefem - stan po konserwacji, fot. A. Cicha 

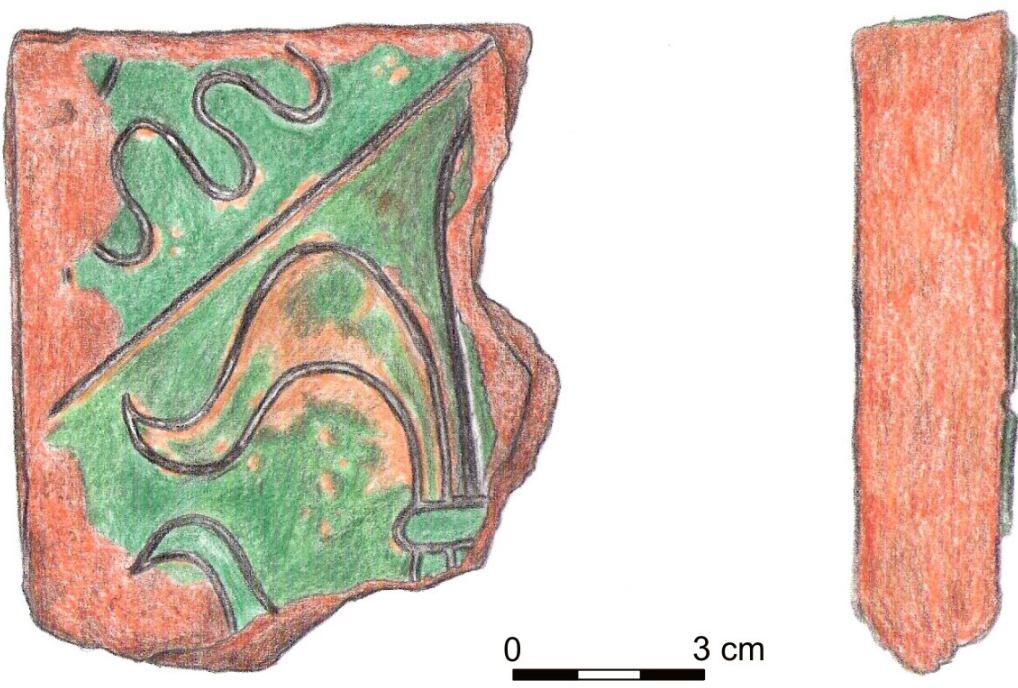

A

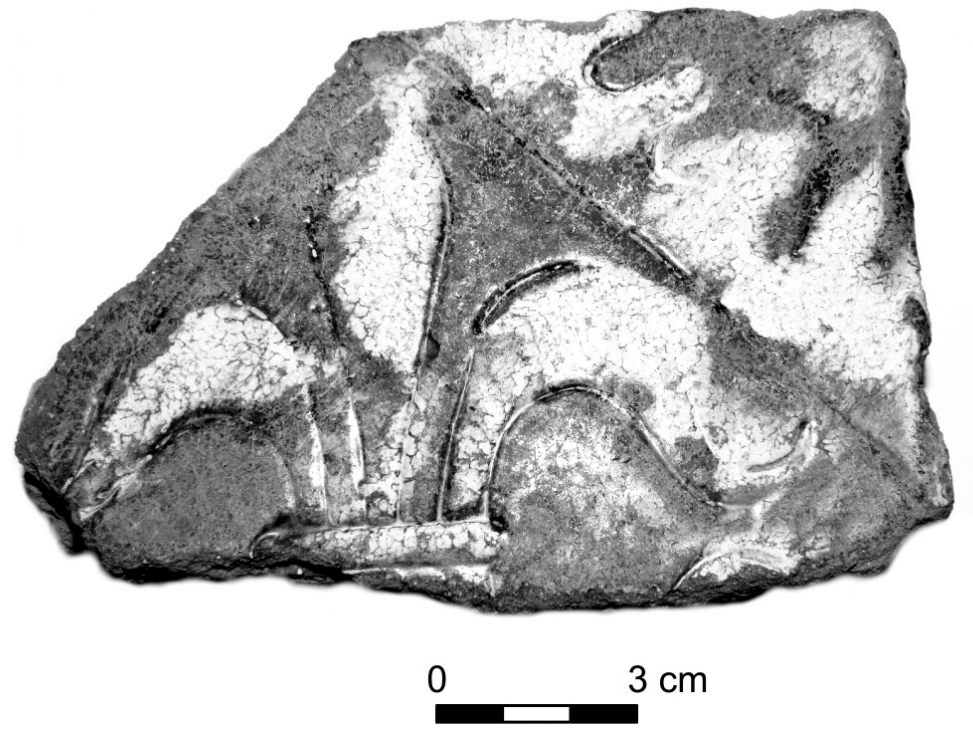

B

Il. 6 oruń, kościół św. Jakuba, badania archeologiczne w 2012 roku - ceramiczne szkliwione płytki posadzkowe zdobione motywem lilii; A - fot. J. Struwe; B - rys. E. Wielocha 

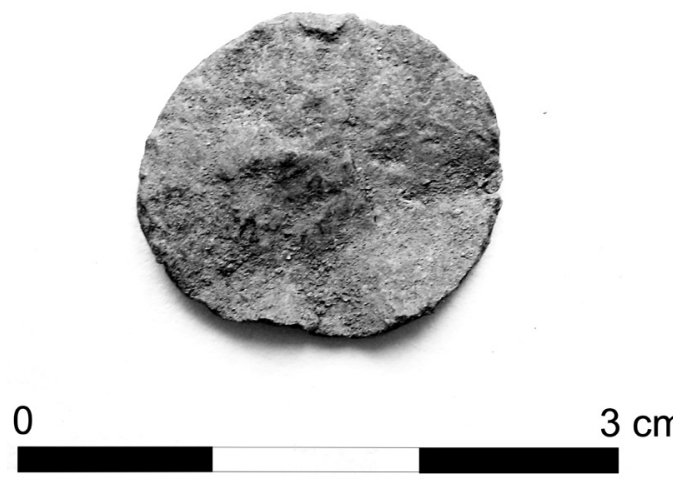

A

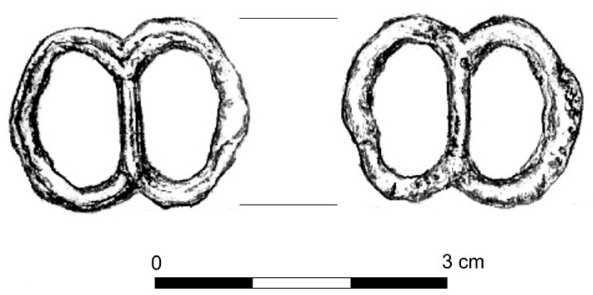

B

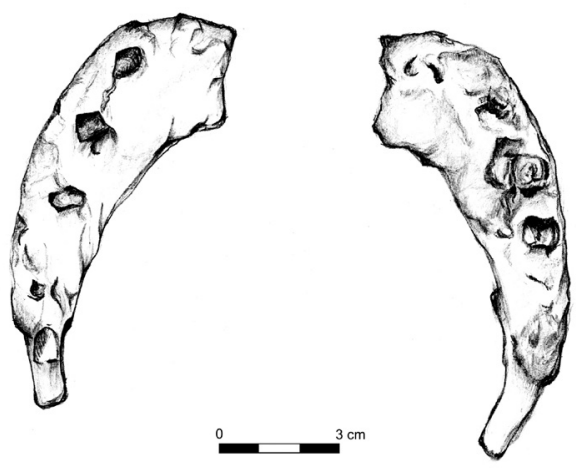

C

Il. 8 Toruń, kościół św. Jakuba, badania archeologiczne w 2010-2012 roku. Metalowe przedmioty znalezione wokół kościoła: A - ołowiany (?) żeton, B - sprzączka (rys. N. Grzeszczuk); C - żelazna podkowa z podkowiakami, D - ołowiana plomba (rys. E. Bełkowska-Kamińska) 


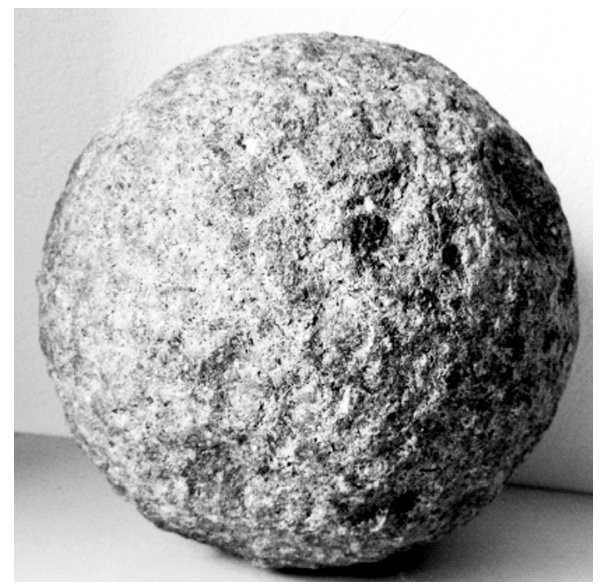

Il. 9 Toruń, kościół św. Jakuba, badania archeologiczne w 2012 roku - kamienna kula działowa (obwód: $53 \mathrm{~cm}$, średnica $17 \mathrm{~cm}$ ), fot. J. Struwe

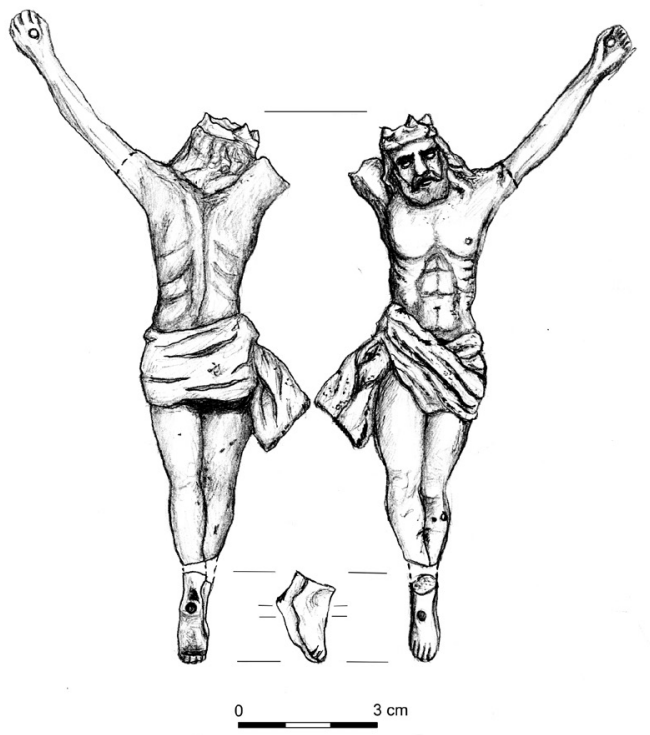

A

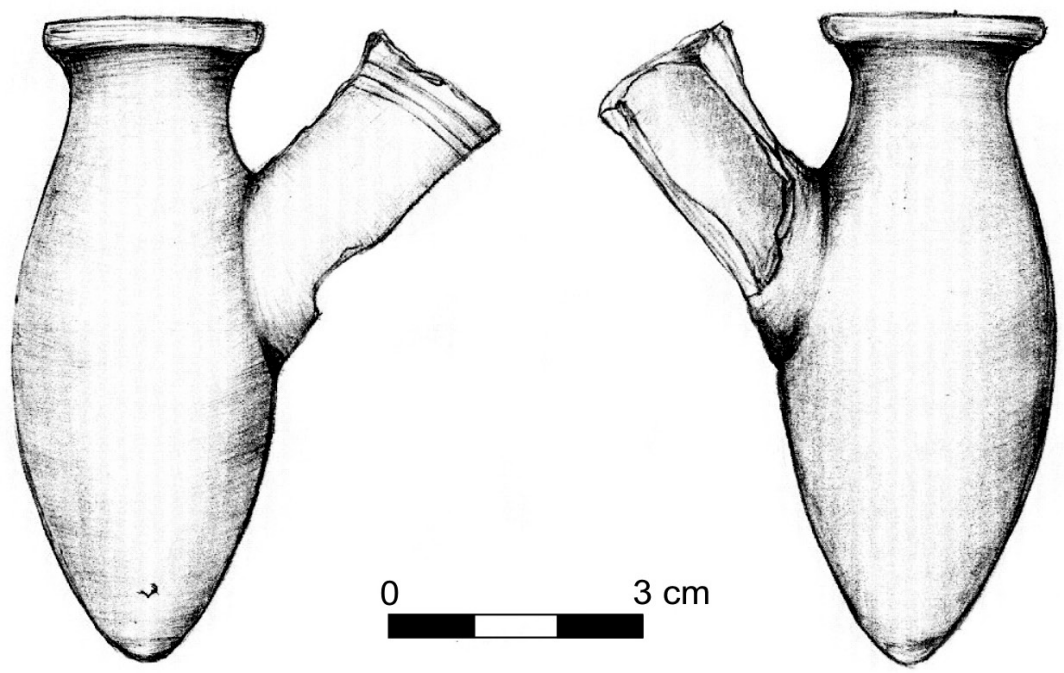

B

Il. 10 Toruń, kościół św. Jakuba, badania archeologiczne w 2011-212 roku. A - główka porcelanowej fajki złożonej, XIX w., rys. J. Ciesielska. B - porcelanowa figura Chrystusa znaleziona przy zakrystii, rys. B. Lechowicz 


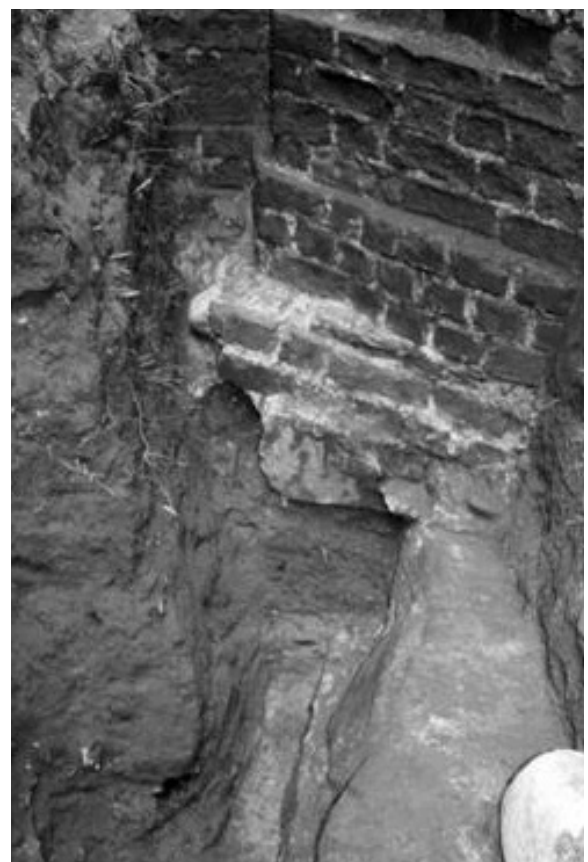

Il. 11 Toruń, kościół św. Jakuba, badania archeologiczne w 2012 roku. Wykop W-10/12 przy bocznym portalu prezbiterium - widok na ceglany fundament wieżyczki schodowej (skośny, w głębi) i (na pierwszym planie) potężny kamienny fundament pod portalem i przyporą, fot. A. Cicha

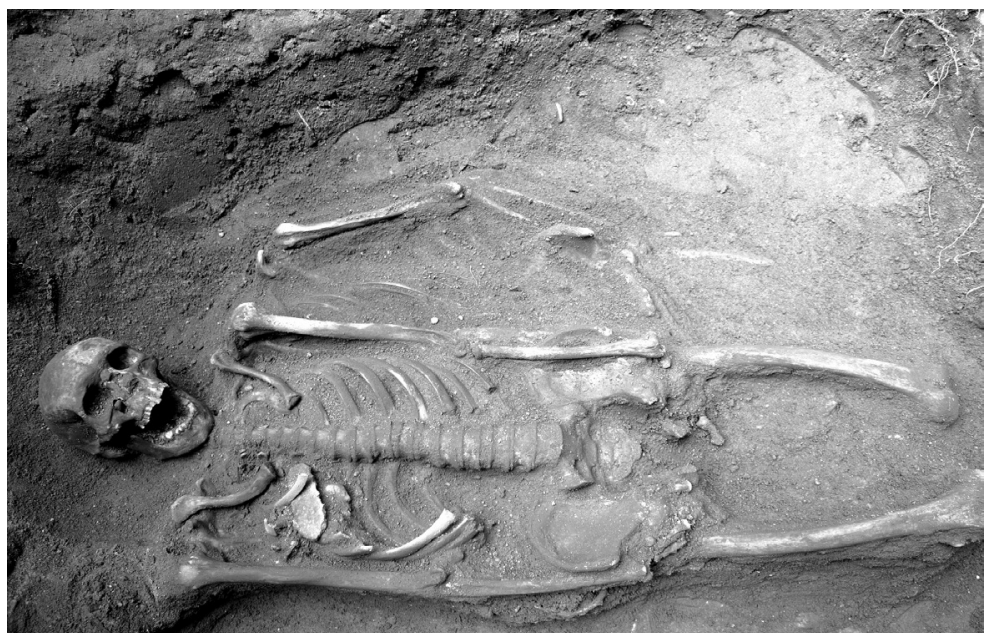

Il. 12 Toruń, kościół św. Jakuba, badania archeologiczne w 2011 roku (wykop W-6/11) - jeden z grobów odsłoniętych na przykościelnym cmentarzu [G-23/11], fot. J. Struwe 